\title{
The Variscan evolution in the External massifs of the Alps and place in their Variscan framework
}

\author{
Jürgen F. von Raumer ${ }^{\mathrm{a}, *}$, François Bussy ${ }^{\mathrm{b}}$, Gérard M. Stampfli ${ }^{\mathrm{c}}$ \\ ${ }^{a}$ Département de géosciences, université de Fribourg, 6, chemin du Musée, 1700 Fribourg, Switzerland \\ ${ }^{\mathrm{b}}$ Institut de minéralogie et géochimie, anthropôle, université de Lausanne, 1015 Lausanne, Switzerland \\ ${ }^{\mathrm{c}}$ Institut de géologie et paléontologie, anthropôle, université de Lausanne, \\ 1015 Lausanne, Switzerland
}

\begin{abstract}
In the general discussion on the Variscan evolution of central Europe the pre-Mesozoic basement of the Alps is, in many cases, only included with hesitation. Relatively well-preserved from Alpine metamorphism, the Alpine External massifs can serve as an excellent example of evolution of the Variscan basement, including the earliest Gondwana-derived microcontinents with Cadomian relics. Testifying to the evolution at the Gondwana margin, at least since the Cambrian, such pieces took part in the birth of the Rheic Ocean. After the separation of Avalonia, the remaining Gondwana border was continuously transformed through crustal extension with contemporaneous separation of continental blocks composing future Pangea, but the opening of Palaeotethys had only a reduced significance since the Devonian. The Variscan evolution in the External domain is characterised by an early HP-evolution with subsequent granulitic decompression melts. During Visean crustal shortening, the areas of future formation of migmatites and intrusion of monzodioritic magmas in a general strike-slip regime, were probably in a lower plate situation, whereas the so called monometamorphic areas may have been in an upper plate position of the nappe pile. During the Latest Carboniferous, the emplacement of the youngest granites was associated with the strike-slip faulting and crustal extension at lower crustal levels, whereas, at the surface, detrital sediments accumulated in intramontaneous transtensional basins on a strongly eroded surface.
\end{abstract}

\section{Résumé}

Évolution varisque dans les massifs externes des Alpes et place dans leur cadre varisque. Dans la discussion générale sur l'évolution Varisque en Europe centrale, le socle pré-Mésozoique des Alpes est souvent inclus avec hésitation. Relativement bien préservés du métamorphisme alpin, les massifs externes des Alpes représentent pourtant un exemple excellent d'évolution du socle Varisque, incluant des microcontinents dérivés de Gondwana avec leurs reliques d'une évolution cadomienne. Les massifs externes témoignent, depuis le Cambrien au moins, de la genèse de l'océan Rhéique. Après la séparation d'Avalonia, la bordure de Gondwana a été soumise à une extension crustale accompagnée de la séparation de microcontinents. L'ouverture de la Paléotéthys, depuis le Dévonien, a eu peu d'influence sur ces massifs. L'évolution Varisque des massifs externes témoigne d'une évolution HP précoce, suivie d'une fusion de décompression sous conditions granulitiques. Pendant le raccourcissement

\footnotetext{
* Corresponding author.

E-mail address: Juergen.vonRaumer@unifr.ch (J.F. von Raumer).
} 
crustal Viséen, les domaines à migmatites et intrusions monzodioritiques en régime transpressionel témoignent d'une situation de plaque inférieure, tandis que les domaines monométamorphiques pourraient être originaires de la partie supérieure des nappes. Durant le Carbonifère supérieur, l'emplacement des granites les plus jeunes fut conditionné par le régime transtensif prévalant dans les niveaux crustaux inférieurs; des sédiments détritiques grossiers étaient déposés simultanément dans des

bassins transtensifs sur une topographie fortement érodée.

Keywords: Variscan basement; External Alps

Mots clés : Socle Varisque ; Massifs externes alpins

\section{Introduction}

Pre-Mesozoic basement areas cover about half of the Alpine domain, and the earliest attempts of a general definition go back to Desor [17,18]. Although strongly involved in the Tertiary tectonometamorphic evolution, the basement is relatively well-preserved in the External realm of the belt (the so-called External Crystalline Massifs, i.e. Gotthard, Aar, AiguillesRouges, Mont-Blanc, Belledonne, Pelvoux, Argen- tera). They record a general evolution common to all terranes composing Pangean Europe (Fig. 1), which comprises Gondwanan (largely between 550$440 \mathrm{Ma}$ ), Palaeotethys-Variscan (largely between 440-300 Ma) and Permian-Alpine periods, respectively. Consequently, a short introduction to the preVariscan evolution of the Gondwana margin will precede the discussion about the Variscan Alps, the post-Permian evolution not really concerning Pangean Europe.

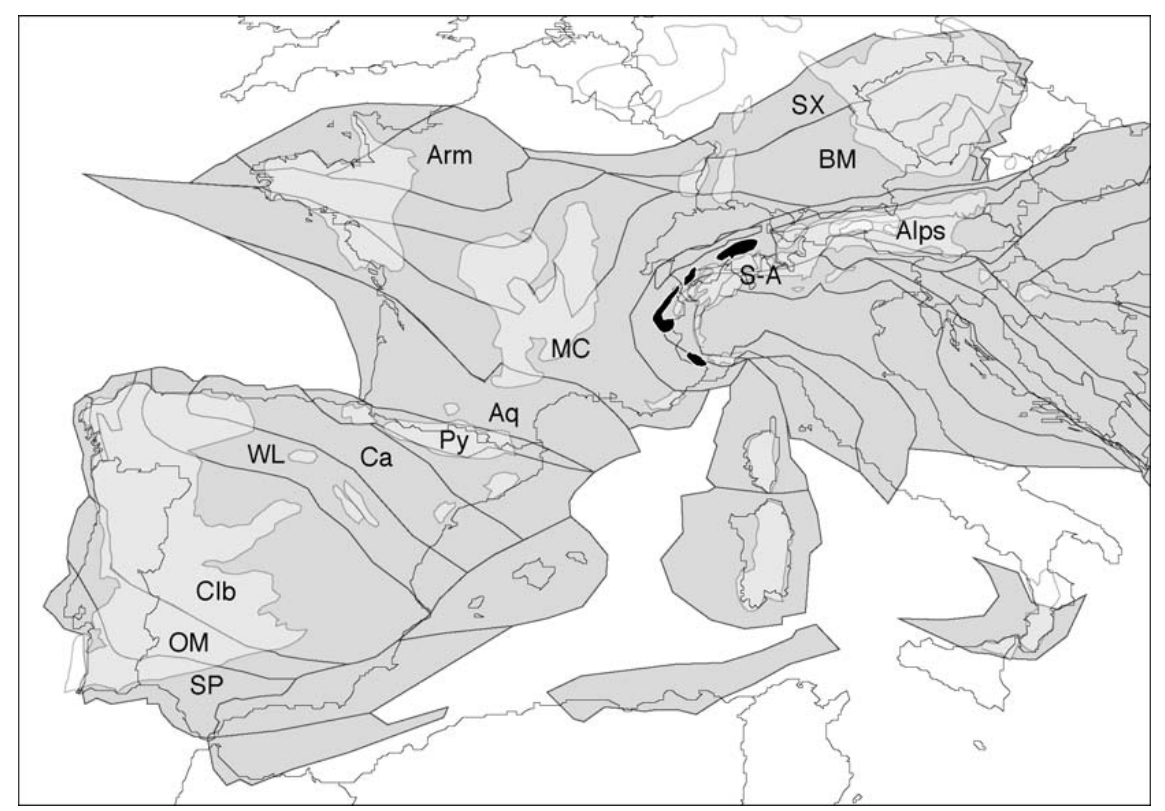

Fig. 1. The External massifs (dark grey, in more detail on Fig. 3) their present-day place among the Central European Variscan basement areas (light grey), and subdivision into terranes (middle grey), first presented in Stampfli et al. [68], inspired by Franke [27,28]. For a better understanding and identification, the contours of the specific terranes are used on Figs. 3 and 5. Dark grey: External massifs, from north to south: Aar-Gotthard, MontBlanc-Aiguilles-Rouges, Belledonne-Pelvoux, Argentera massifs. AM: Armorica; Aq: Aquitaine; BM: Bohemian massif; Clb: Central Iberian, Ca: Cantabrian terrane; MC: French Central Massif; OM: Ossa Morena; Py: Pyrenees; SP: South Portuguese; SX: Saxothuringia; WL: West AsturianLeonese.

Fig. 1. Position actuelle des massifs cristallins externes (gris foncé, détail : Fig. 3), parmi les socles Varisques européens (en clair), et subdivision originale en terranes (gris moyen) selon Stampfli et al. [68] inspiré de Franke [27,28]. Pour une meilleure compréhension et identification, les contours de terrains spécifiques ont été utilisés sur les Fig. 3-5. En noir : massifs externes, du nord au sud : Aar-Gothard, Mont-Blanc-AiguillesRouges, Belledonne-Pelvoux, Argentera. AM : Armorica ; Aq : Aquitaine ; BM : massif Bohémien ; CIb : Ibérie centrale ; Ca : terrane Cantabrien ; MC : Massif central français ; OM : Ossa Morena ; Py : Pyrénées ; SP : Zone sud-portugaise ; SX : Saxothuringien ; WL : zone ouest-AsturienneLéonaise. 


\section{Pre-Variscan relics in the Alps}

The Gondwanan origin of Alpine basement areas has been largely discussed [74,82], and all pre-Variscan events are actually related to the evolution of Gondwana and its northern margin (Fig. 2). According to reconstructions [67], the active margin setting (Neoproterozoic-Earliest Cambrian), followed by Late Cambrian back-arc rifting (Chamrousse event) and a subsequent general crustal extension, led to the opening of the Rheic Ocean and the contemporaneous separation of Avalonia from the western part of the Gondwana margin. At the eastern Gondwana margin, subsequently to Late Cambrian back-arc rifting, a short subduction-collision event interrupted the crustal extension before the general opening of the eastern branch of the Rheic Ocean [77].

Age data from Alpine basement areas [32,56] show an inheritance of detrital material $(1.0,1.7,2.0$ and up to $3.17 \mathrm{Ga}$ ) from source areas either located in the West African shield, or possibly derived from the Hunia blocks or eastern Gondwana [81]. In addition to already presented information about the Neoproterozoic-Early Palaeozoic evolution and Cambro-Ordovician magmatic rocks [82], the Neoproterozoic-Early Palaeozoic evolution of the Austroalpine basement in the South of the Tauern Window has been reported [62], and a Cambrian oceanic magmatism was shown in the lower Penninic nappes of the Ticino area [58]. In the External massifs, the Late Cambrian Chamrousse ultramafic body $[37,47,48,51]$, and evidence for Ordovician orogenic events (e.g. Gotthard area [52], Aar massif [56]) remain important milestones. A Cambrian gabbro reported from the Argentera massif [54] completes the information about the Chamrousse back-arc rifting event, and the presence of an Early Palaeozoic Greenstone Unit in the southeastern part of the Aiguilles-Rouges massif [21] could represent a comparable tectonic environment.

Of specific interest for the Early Palaeozoic evolution of the External massifs are the local observations of an assemblage of eclogites, granulites and ultramafics, hosted in a strongly migmatised metasedimentary and metagranitoid series of Early Palaeozoic age (Lac Cornu, Aiguilles-Rouges [75,79]). Such assemblages may correspond to structures observed in the western prolongation of the External massifs, in the Upper Gneiss Unit [40] of the French Central Massif, specifically to the so-called leptyniteamphibolite complexes (comp. [23]). Equally, the great resemblance with corresponding structures observed in the Maures massif [1] may lead to the interpretation as parts of a Lower Palaeozoic supra-subduction setting along the Gondwana margin. More detailed research has to prove such an interpretation.

Relics of former, more complete, Early Palaeozoic lithostratigraphic columns in the External massifs (e.g. in the Aiguilles-Rouges area) seem to represent just the reduced Early Cambrian lithologies, such as observed in boreholes from the Saxothuringian domain (see the discussion in: von Raumer and Bussy [76]). Striking similarities in subsidence curves of Lower Palaeozoic sediments from the Gondwana margin seem to indicate that the Late Neoproterozoic and reduced Early (Lower)

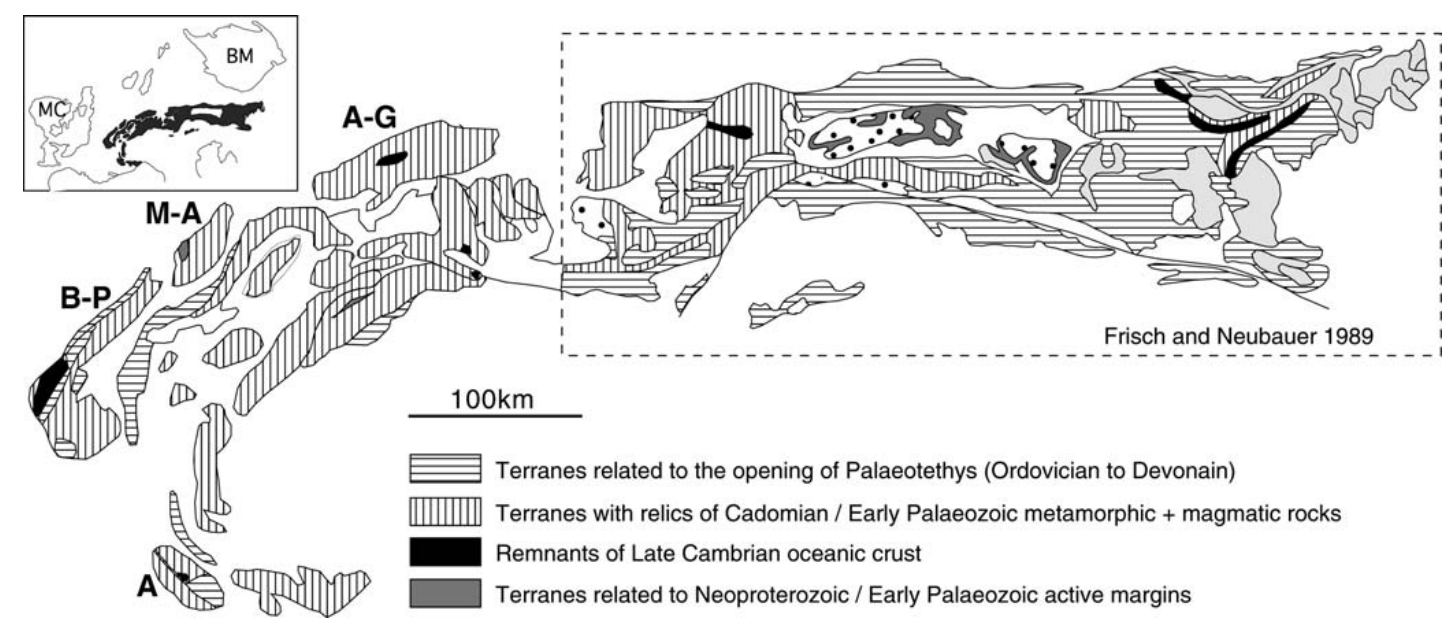

Fig. 2. Alpine pre-Mesozoic basement areas and reinterpretation of their former plate-tectonic situation at the Gondwana margin, redrawn from von Raumer et al. [81] with new plate-tectonic attributions. A: Argentera massif; B-P: Belledonne and Pelvoux; M-A: Mont-Blanc-Aiguilles-Rouges; A-G: Aar and Gotthard massifs.

Fig. 2. Terranes du socle pré-Mésozoïque alpin et réinterprétation de leur situation en termes de plaques tectoniques à la marge gondwanienne, repris de von Raumer et al. [81]. A : massif d'Argentera ; B-P : Belledonne-Pelvoux ; M-A : Mont-Blanc-Aiguilles-Rouges ; A-G : massifs de l'Aar et du Gothard. 
Cambrian lithologies were preserved from the Late Cambrian uplift and erosion of a former, more complete, Cambrian lithostratigraphic column [77], this being the image of the stepwise crustal extension and rifting at the Gondwana margin. It may be worthwhile to mention, that the well-known "Erlan felses" of the Saxothuringian and Moldanubian have their lithostratigraphic parallels in all basement areas of the External domain, but are also currently observed in the southern Alps. The magmatic evolution in most Alpine basement areas is characterized by Ordovician calk-alkaline granitoids, as found in most of the Early Palaeozoic European framework [83].

The most recent reconstruction for the general Cambrian situation (Figs. 2 and 3) displays the Gondwana-derived terranes forming the future Variscan Europe and the Hunia blocks, as well as the main lines of Early Cambrian and Ordovician rifting (compare the corresponding subsidence pattern in: von Raumer and Stampfli, and von Raumer et al. [77,84]). The Late Cambrian Chamrousse back-arc rifting is seen as a major structural feature at the Gondwana margin [77], which shows all the criteria corresponding to stepwise crustal extension observed at different crustal levels. The rifting tendencies continued during the installation of a passive margin setting recorded in OrdovicianSilurian subsidence patterns and by the emission of large volumes of volcanic rocks [77], in relation to the opening of the eastern branch of the Rheic Ocean. In the External massifs, Ordovician magmatism is represented by MOR-derived basic rocks and large volumes of augengneisses [53,55,59,81], as well as acidic volcanics [55], in a very similar pattern to that observed in the Noric Terrane of the eastern Alps [29].

\section{Variscan evolution in the External domain}

Despite the Alpine overprint, much work has been done since the 18th century to elucidate the pre-Alpine geological evolution in the Alps. After early synthesis attempts [71-73], a more general view resulted from a vast coordination program [76], and it appears that Variscan terranes in the Alps are, in general, Gondwanaderived microcontinents [74]. Considering the External Alpine realm, it is convenient to distinguish between Early and Late Variscan evolutions, which will be treated separately.

\section{The Early Variscan evolution}

Most of the Variscan basement areas consist of variously migmatized polymetamorphic lithologies.
Despite this high-temperature overprint, Variscan pressure-temperature-time paths have been established for distinct regions, which display differences in their respective metamorphic evolution $[19,78,80]$. In all External massifs, we can thus distinguish between Early Palaeozoic and Devonian-Carboniferous monocyclic (low-grade Variscan metamorphism) from polymetamorphic areas (Cadomian-Early Palaeozoic heritage and Variscan high-grade metamorphism).

\section{Monometamorphic evolution}

The southwestern part of the Belledonne massif is characterised by an assemblage of "mono-metamorphic" tectonic slices comprising the Cambrian Chamrousse ophiolite, the Devonian volcanic Rioupéroux-Livet series, and the Taillefer Carboniferous sediments $[47,48]$. The Chamrousse area is underlain by an ultramafic complex and its sedimentary cover in inverse position, representing one of the most important Upper Cambrian pieces of oceanic crust. The monometamorphic evolution of the Rioupéroux-Livet volcanic-plutonic series, mostly underlain by a polymetamorphic basement, is a rare witness of Devonian evolution, where metasediments, volcaniclastics, amphibolitic and leucocratic gneisses, metatrondhjemites, -keratophyres and -basalts [46] record a volcanoplutonic evolution of an attenuated continental crust [50]. This interpretation is integrated in the present-day large-scale reconstructions (see below). The Taillefer series includes detrital series with few conglomerates, carbonates, and volcanics of probably Devonian to Late Visean age.

The southwestern part of the Aiguilles-Rouges massif is also composed of various tectonic units [19,21], comprising a basement of amphibolite-facies grade and a complex greenstone volcanosedimentary unit. Although for the latter, an Early Palaeozoic evolution is supposed, a younger age, like Devonian, cannot be excluded. Comparable to the Belledonne evolution, Visean to Upper Carboniferous detrital sediments define an intramontaneous setting.

Moreover, in the Argentera, the Pelvoux/Haut Dauphiné and the Gotthard-Aar massifs, comparable distinctions of polymetamorphic basement and slices of monocyclic series are observed (references and details in von Raumer et al. [80]) and it is supposed that the alternating juxtaposition of high- and low-grade tectonic assemblages in all parts of the external domain probably resulted from upper and lower plate setting after transpressive evolution. 


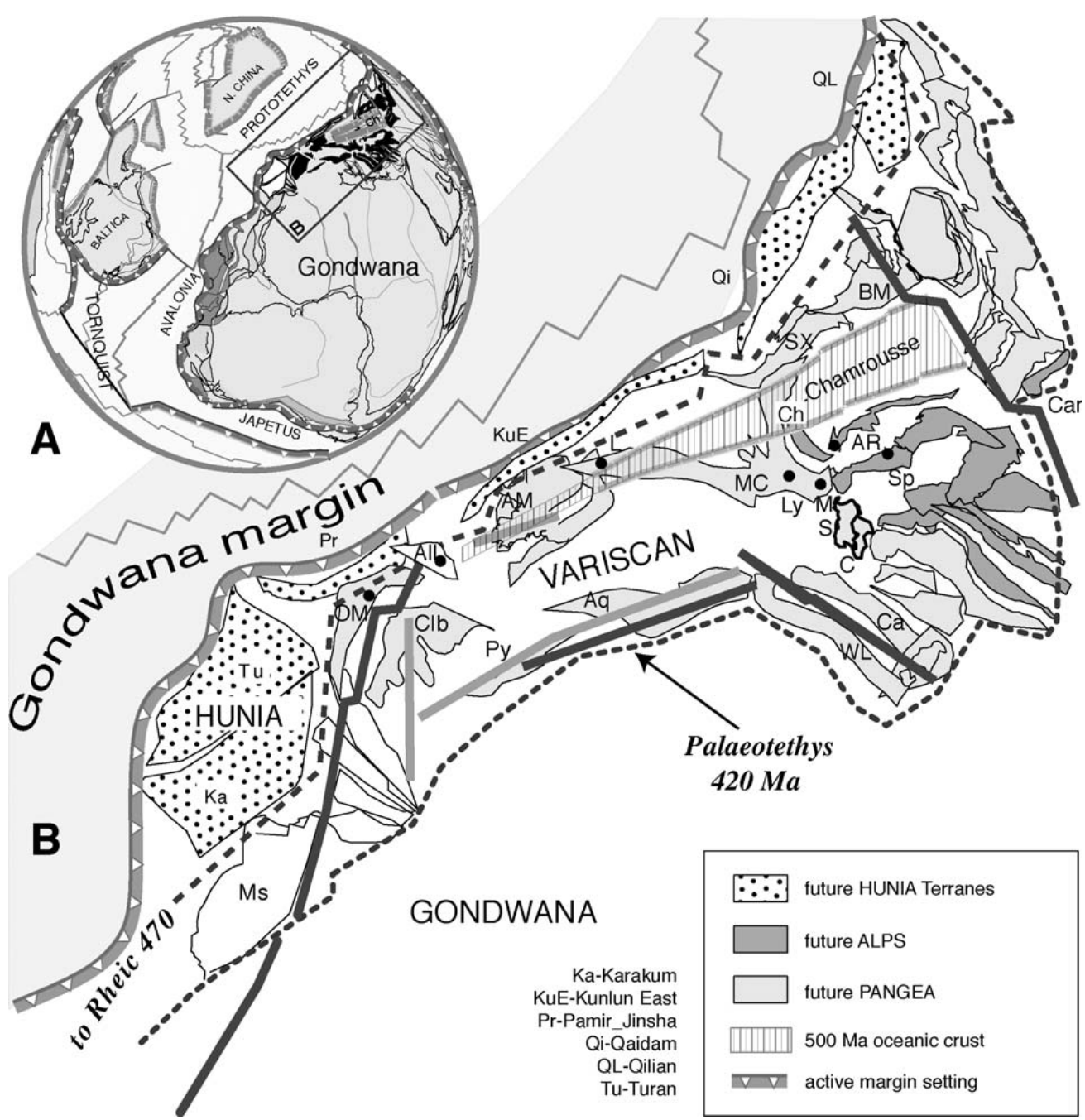

Fig. 3. A. Global Cambrian reconstruction. B. Detail sketch of a possible Late Cambrian reconstruction (500 Ma) of the Gondwana margin with the traces of the future oceanic opening of the eastern branch of the Rheic Ocean (470 Ma) and the Palaeotethys rifting. Dark lines: location of Early Cambrian rifting; grey lines: location of Ordovician rifting (comp. [62]). All: Iberian allochthonous; Aq: Aquitanian basement; AM: Armorican massif; BM: Bohemian massif; Ca: Cantabrian terrane; Clb: Central Iberian; MC: Massif Central; Ms: Moroccan meseta; OM: Ossa Morena; Py: Pyrenees; SX: Saxothuringian; WL: West Asturian-Leonese.

Fig. 3. A. Reconstruction globale pour le Cambrien. B. Reconstruction schématique possible de la marge gondwanienne pour le Cambrien (500 Ma), avec les traces de l'ouverture du futur océan Rhéique oriental (470 Ma) et indication du rift de la Paléotéthys. Lignes foncées : localisation de l'extension durant le Cambrien inférieur ; lignes grises : localisation de l'extension durant l'Ordovicien [62]. All : allochthone Ibérien ; Aq : socle Aquitanien ; AM : massif Armoricain ; BM : massif Bohémien ; Ca : terrane Cantabrien ; CIb : Ibérie centrale ; MC : Massif central ; Ms : meseta Marocaine ; OM : Ossa Morena ; Py : Pyrénées ; SX : Saxothuringien ; WL : zone Ouest Asturienne-Léonaise.

\section{Polymetamorphic evolution}

Most of the outcrop areas of the External massifs record a polymetamorphic history, whose metamorphic, magmatic and tectonic evolutions will be discussed separately.

\subsection{Metamorphic evolution}

Although migmatites after Early Palaeozoic sediments and Ordovician orthogneisses predominate, relics of earlier HP-rocks and eclogites have been preserved. A HP-HT event and subsequent decompression-cooling has been identified in several basement areas [61,80] where, subsequent to eclogite conditions, a succession of kyanite-, sillimanite- and andalusite-bearing parageneses is observed. In the Aiguilles-Rouges massif [78], tonalitic granulitefacies ky-bearing melts, produced under conditions of about $800{ }^{\circ} \mathrm{C} / 140 \mathrm{MPa}$ (Fig. 4), represent probably an early generation of Variscan melts. The corresponding granulitic garnets contain relics of a staurolitephengite assemblage, suggesting the existence of former eclogitic schists, common in high-pressure 


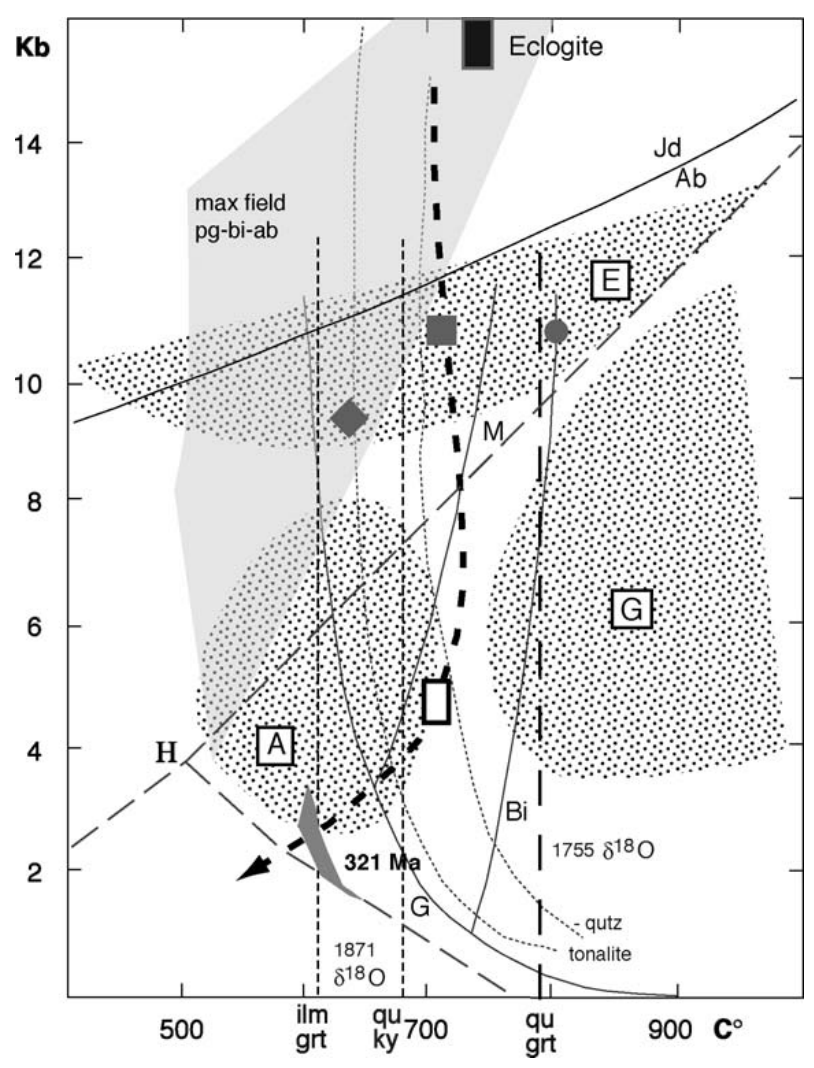

Fig. 4. Main P-T evolution in the polymetamoprhic basement of the External massifs, example from the Aiguilles Rouges massif, including dehydration melting of metasedimentary rocks and stable isotope data from the Lac Cornu area [78]. Fields of eclogite- (E), granulite- (G), amphibolite-facies (A), solidus of granites $\mathrm{G}$ with dehydration melting curves (M - muscovite; Bi - biotite), after [69]; tonalites after [85]; eclogite from [61]; Black dot, diamond, square: dehydration melting of former metasediments and amphibolites. Open rectangle: Salanfe, migmatite melting after [11]; dark grey polygone: migmatisation at Emosson area, Aiguilles Rouges, after [33]; H: Al-silicate triple point after [38]. Field of maximum stability of pg-bi-ab after [54].

Fig. 4. Évolution pression-température du socle poly-métamorphique des massifs externes alpins, exemple des Aiguilles Rouges, avec indication de la fusion par déshydratation de métasédiments, et données d'isotopes stables de la région du Lac Cornu [78] ; Champs éclogite- (E), granulite- (G), faciès amphibolite $(\mathbf{A})$, solidus du granite $\mathrm{G}$ avec lignes de fusion anhydre (M - muscovite ; Bi - biotite), d'après [69] ; tonalites d'après [85] ; éclogite de [61] ; point, polygone et carré noirs : fusion d'anciens métasédiments et amphibolites. Rectangle blanc : fusion et formation de migmatites à Salanfe selon [11] ; polygone gris foncé : migmatites de la région d'Emosson, Aiguilles Rouges, d'après [33] ; H : point triple des silicates d'alumine d'après [38]. Champ de stabilité maximale de pg-bi-ab d'après [54].

terrains. Formation of spinel- or corundum-cordierite rims around kyanite crystals records subsequent decompression. Early Palaeozoic (pre-Ordovician) micaschists with garnet-bearing plagioclase megablasts (up to $10 \mathrm{~cm}$ in size) could also represent former eclogite schists, where sodium-rich assemblages like albite-paragonite-phengite or jadeite (comp. [54]) may have predominated [76]. Zircons from the granulitic melts, yielding $\mathrm{U}-\mathrm{Pb}$ ages ranging from ca 460 to $560 \mathrm{Ma}$ (unpublished LA-ICPMS), supposedly represent the spectrum of detrital zircons. Outer growth rims, which were too narrow to be probed by laser ablation, are ascribed to the melting event, which might be Devonian to Early Carboniferous in age, when comparing with corresponding high-pressure units from the upper gneiss nappe of the French Central Massif (comp. [23]), where PT-evolutions show striking similarities. Equally, astonishing resemblances appear with zircons observed in the allochthonous terranes of the NW Iberian Variscan belt [25], which also formed by decompression of former HPunits.

Granulitic rocks were also identified in the other External massifs. A Variscan evolution of granulites is reported in the Pelvoux (Peyre-Arguet area [35]), and HP-LT relics in Belledonne underwent nappe stacking and decompression during the Visean to Westphalian time period [36]. Granulitic xenoliths have been found in Silurian dacites or in migmatites in the Argentera massif $[13,14,42,55]$, and a comparable PT-evolution has been presented recently for that area [26], confirming the general decompression path from HPgranulites to amphibolite-facies rocks. Granulite mineral parageneses were also observed in the Aar 
and Gotthard massifs [79]. For the latter, it is not yet established if all these HP-assemblages are only of Ordovician age, or if that evolution ends during the Early Variscan [55]. Visean granulites and lower crustal melts (compare the magmatic evolution, below) have to be supposed for the External domain and, for comparison, such an evolution is discussed for the Vosges $[57,58,60]$.

\subsection{Magmatic evolution}

Since an earlier synthesis [2], high-precision U-Pb zircon dating has allowed a considerable refinement of the magmatic evolution in the External massifs, which consists of short magmatic pulses rather than a protracted activity over tens of millions of years. New age data confirm the narrow relationship between metamorphic, tectonic and magmatic events [6]. During the Early Carboniferous, the tectonic context of the decompression of lower crustal elements is responsible for the generation of durbachitic melts (monzodioritic to quartzdioritic composition), known in all External massifs as $\mathrm{Mg}-\mathrm{K}$ granitoids [76,81], where the Gneiss d'Olan in the Pelvoux area [41] and the $\mathrm{K}-\mathrm{Mg}$ granitoids of the Belledonne area [50] exhibit in the best way the complex evolution of the most basic members of this volcanic series. Similar rocks are described in the Bohemian massif and in the French Massif Central (Vaugnerites- $\mathrm{Mg}-\mathrm{K}$ melasyenites?). They typically emplaced syntectonically between 340 and 330 Ma $[15,16]$ along major dextral strike-slip faults, often hosting meter-sized comagmatic mafic enclaves of mantle origin [6]. These $\mathrm{Mg}-\mathrm{K}$ magmas are thought to result from partial melting of a high-K lithospheric mantle (metasomatized during an earlier subduction event) with a variable contribution of crustal material $[6,12,39]$. Minor S-type anatectic melts of crustal origin are generated by heat advection from the mantle-derived magmas.

Subsequently, the entire area experienced a Barrovian-type metamorphic evolution, where paragneisses of favorable composition underwent in situ decompression melting at $320 \pm 1 \mathrm{Ma}(\mathrm{U}-\mathrm{Pb}$ monazite dating [6,33]). The continental lithosphere progressively recovered its original thickness in a transcurrent to extensional tectonic regime (Fig. 5) ascribed to the rollback effect of the subducting Palaeo-Tethys slab (backarc extension).

\subsection{Tectonic evolution}

Consistent structural data were published from the southwestern part of the Aiguilles-Rouges $[19,20]$ and from the central parts of the Aiguilles-Rouges and the Mont-Blanc areas [61,82]. Pervasive foliation-planes $\left(\mathrm{S}_{2} / \mathrm{S}_{3}\right.$, mostly a composite set of superposed foliations resulting from continuous deformation accompanied by rotation), orientation patterns of lineations, and fold axes show a rather homogeneous distribution of the structures, which should be correlated with the Variscan metamorphic and magmatic evolution.

In the northeastern part of the Aiguilles-Rouges massif, a large-scale NE-SW trending mylonite zone and adjacent areas represent an evolution from prograde to retrograde metamorphic stages during progressive noncoaxial deformation in a transpressional deformation regime, where early fold axes were rotated into the direction of stretching with formation of coaxial sheath-folds [76], all followed by late strike-slip deformation during anatectic melting (see above [33]) and intrusion of the youngest granitoids (e.g. Vallorcine granite). In the central part of the Aiguilles-Rouges massif, an evolution from the burial of lithological units during oblique collision, followed by syndeformational uplift with formation of a steeply dipping pervasive foliation, and subsequent exhumation during late Variscan strike-slip faulting is documented. In the southwestern Aiguilles-Rouges massif $[19,20]$, the bulk deformation is divided into an early stage of crustal shortening associated with prograde metamorphism, and a subsequent pervasive transpressional deformation, during which the rocks were exhumed. In the Belledonne area [24,36,49] a complex evolution from Visean nappe stacking of HPLT units and the subsequent cooling-decompression path led to Late Variscan extension.

\section{Late Variscan evolution}

During the Late Carboniferous, high exhumation and erosion rates reflect the general collapse of the Variscan belt, as recorded in intracontinental detrital basins. In the Salvan-Dorenaz basin of the Aiguilles-Rouges massif, ca. $1700 \mathrm{~m}$ of fluvial, alluvial fan and volcanic deposits were accumulated with average subsidence rates of about $0.2 \mathrm{~mm} /$ year [10], recording fast uplift (ca. $1 \mathrm{~mm} / \mathrm{year}$ ) and vigorous erosion [7,8]. The sedimentary trough, formed between 308 and $293 \mathrm{Ma}$, testifies to contemporaneous unroofing of basement and magmatic activity during transtensional tectonics [9].

At midcrustal levels, several peraluminous magmatic bodies intruded simultaneously at $307 \mathrm{Ma}$ [6], either syntectonically as vertical, sheet-like intrusions within major dextral transtensive zones (Vallorcine and 
Montenvers granites), or as a large mass of mobile migmatites (fully anatectic granodiorite). Stable isotopes document fluid exchange between surface and intrusion levels for the Vallorcine granite [3]. Comagmatic gabbros and mafic microgranular enclaves demonstrate a mantle magmatic input. The large $304 \mathrm{Ma}$, alkali-calcic, Fe-K-rich Mont-Blanc granite is the youngest intrusion in the area, supposed to have emplaced in a pull-apart structure during large-scale strike-slip faulting [43]. Comagmatic mafic rocks occurring as monzodioritic microgranular enclave swarms, stocks and synplutonic dykes, again document a mantle activity [5].

In summary, the systematic association of Al-rich, crust-derived melts, on the one hand, and mantlederived mafic melts with variable amounts of crustal contamination, on the other hand, characterizes the Carboniferous granite magmatism in the External massifs. Their emplacement is influenced by lithospheric-scale transcurrent faults [4]. The minor volumes of anatectic melts produced by in situ decompression melting must be considered separately. The following scenario is proposed [6]:

- deep-seated crustal rocks are heated up through thermal relaxation after crustal thickening due to the Variscan accretion;

- the thickened lithosphere is reequilibrating through extension and exhumation/erosion at upper crustal level, through delamination and upwelling at the lithosphere-asthenosphere boundary;

- the metasomatized lithospheric mantle is melting, $\mathrm{Mg}-\mathrm{K}$ liquids are produced and emplaced in upper crustal levels through lithospheric-scale faults;

- hot midcrustal rock units experience in situ decompression melting while uplifted;

- as the crust is thinning, the asthenospheric mantle is upwelling and mafic melts evolve towards more primitive composition, underplating the crust;

- mafic magmas bring more heat to the already hot lower crustal levels, triggering large-scale dehydration melting of various lithologies;

- large volumes of magmas are extracted and collected along active crustal-scale faults and move syntectonically to higher levels.

\section{Variscan plate-tectonic evolution}

Before considering the plate-tectonic evolution in the more general framework, it may be interesting to find possible parallels of evolution between the External massifs and the adjacent areas. The parallels of a generally oblique active margin-setting during the Devonian-Visean involving lower crustal units and contemporaneous formation of Visean $\mathrm{Mg}-\mathrm{K}$ granitoids (Durbachites, Vaugnerites) in the French Massif Central and the External massifs had already been discussed [74], proposing the existence of a major suture zone (comp. Fig. 5), where continental pieces of an archipelago-like ribbon-continent followed a dextral strike-slip system during contemporaneous oblique subduction. Also, the Devonian evolution in Belledonne and in the Brevenne-Lyonnais basin [30,31], interpreted as a Devonian rift in an attenuated continental crust [50], is a time-parallel evolution which may coincide with the opening of the Palaeotethys. A further parallel may exist in the chaotic assemblages of serpentinites, granulites, metaperidotites, and eclogites, hosted in former metapelitic metasediments of the Aiguilles-Rouges [76,79], which could correspond to certain "leptynite-amphibolite complexes" of the upper gneiss nappe of the French Central Massif and the Maures massif (see above). Consequently, the Variscan plate-tectonic evolution of the basement areas hidden in the Alpine domain should not be interpreted independently.

In a more general view, the Variscan plate-tectonic evolution is proposed on Fig. 6. In a first step (Fig. 6A), the earliest Variscan HP-evolution observed in the European Variscides, usually related to the northward subduction underneath the Laurentian-Baltica margin [44], is interpreted here as an early Variscan (400 Ma) obduction [68], producing the complex stacking of the former subducting oceanic crust (intra-Rheic Ocean) and eclogites above HP-units representing the Gondwana margin (Fig. 6A). An intraoceanic subduction, north of the Gondwana passive margin, is necessary to explain the widespread occurrence of ophiolites and HP pressure rocks found on this margin, and emplaced southward before the Variscan final collision. Subduction reversal (Fig. 6B) led to the subsequent drifting (since $370 \mathrm{Ma}$; Fig. 6C) of a continental ribbon detached from the northern margin of Gondwana (the Galatian superterrane, first presented [66], and published [77]), including, in particular, the basement of the external Alps. These crustal blocks show the early Variscan decompressional melting of former granulites and the intrusion of durbachitic melts discussed above. The Galatian terrane subsequently collided with the socalled Hanseatic terrane [66,77], detached from Laurasia during the opening of the Rhenohercynian ocean (Early Devonian; Fig. 6C). The collision resulted in a cordillera (Fig. 6D, E), which was finally accreted to Laurussia ca. $320 \mathrm{Ma}$ ago (Fig. 6G). At the same 


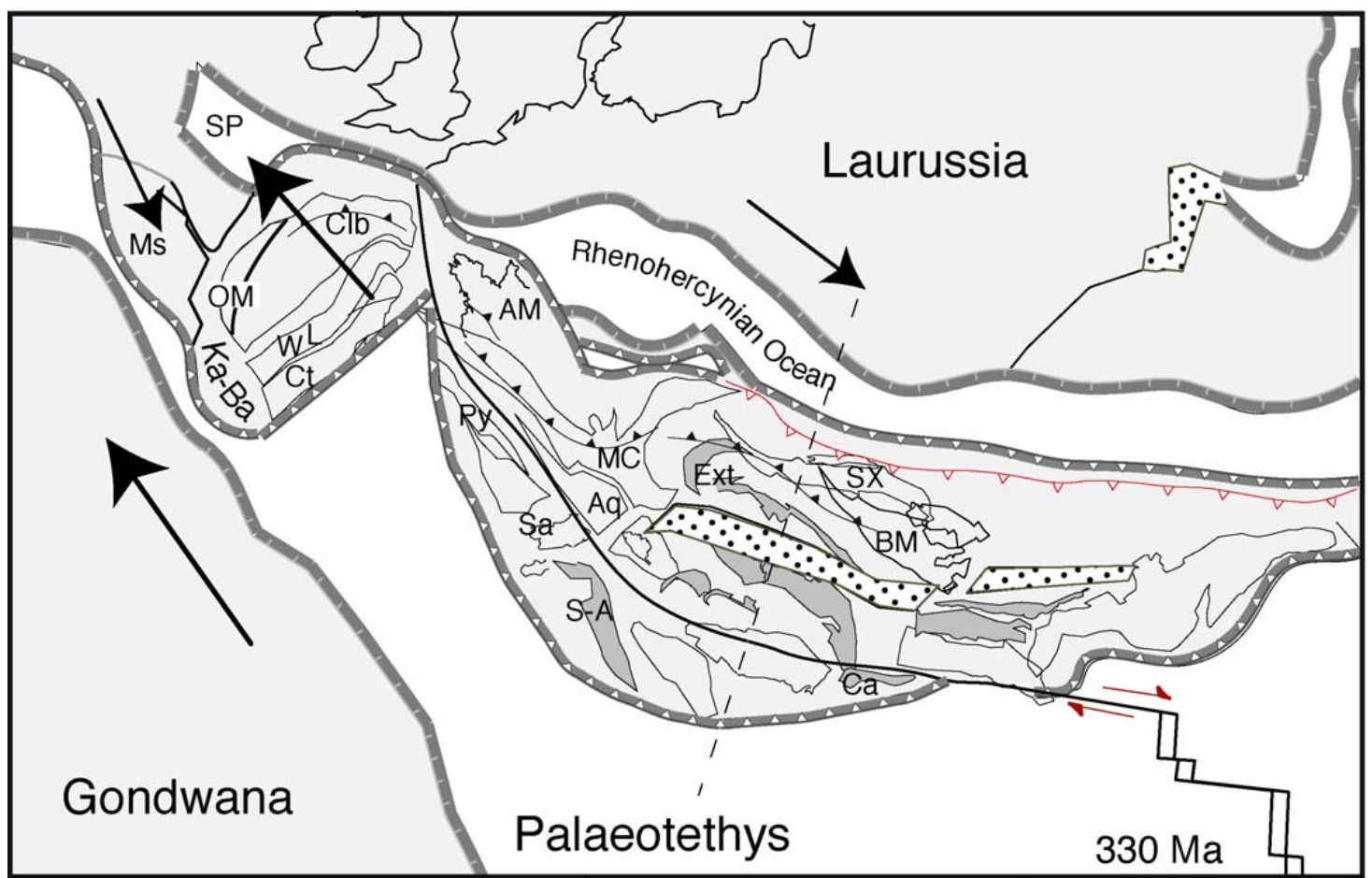

STRIKE-SLIP

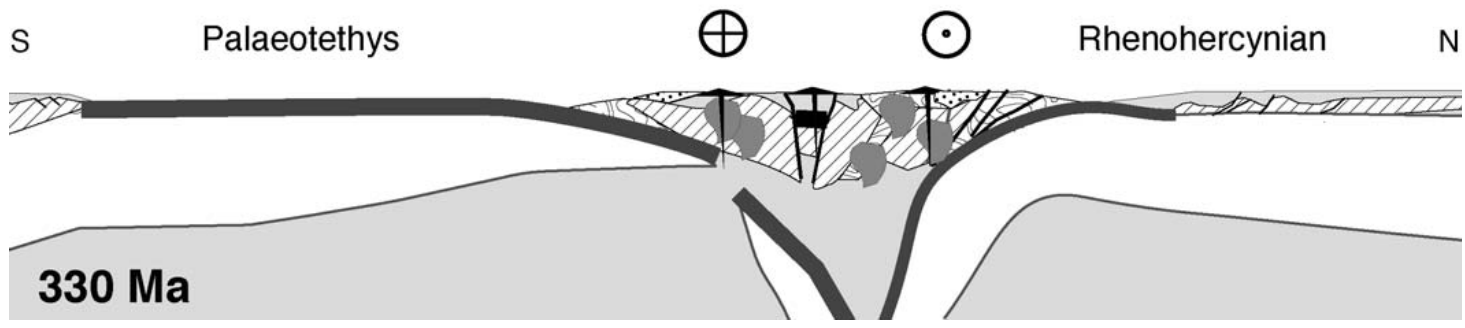

Fig. 5. Plate tectonic sketch of the Galatian ribbon continent (location of terranes, comp. identical contours on Fig. 1) and possible section (dashed line) for the Carboniferous (330 Ma, comp. with the different global interpretation [45]). Strike-slip of major terrane assemblages and contemporaneous oroclinal bending of the Iberian-Armorican segment. Former north-directed underplating resulted from obduction of intraRheic oceanic crust on the Gondwana margin. The early collision of the Iberian-Armorican segment with Laurussia interrupted the former continuity between the Rhenohercynian Ocean and the South-portuguese Zone, a former relationship which is not recognized in present-day reconstructions [44], comp. Fig. 6. Dark grey: future Alpine terranes; stippled areas: Late Carboniferous transtensional troughs; AM: Armorican massif; Aq: Aquitaine; BM: Bohemian massif; Ca: Carnic Alps; Ct: Cantabrian terrane; Clb: Central Iberian; Ext: External Alpine domains; Ka-Ba: Kabyles-Baleares; MC: Massif Central; Ms: Moroccan meseta; OM: Ossa Morena; Py: Pyrenees; Sa: Sardinia; S-A: Southern Alps; SP: future South-Portuguese Zone; Sx: Saxothuringian; WL: West Asturian-Leonese terrane.

Fig. 5. Schéma tectonique du continent ruban Galatien (location des terranes, comparer avec les contours identiques sur la Fig. 1) et coupe nord-sud (ligne interrompue) pour le Carbonifère (330 Ma, comparer avec l'interprétation tectonique différente [45]). Cisaillement dextre d'assemblages de terranes et flexure oroclinale du segment Ibéro-Armoricain. L'ancienne subduction de direction nord (triangles noirs) résultait de l'obduction de croûte intraocéanique sur la marge gondwanienne. La collision précoce du segment Ibéro-Armoricain avec la Laurussie a interrompu la liaison de l'océan Rhéno-hercynien avec la zone portugaise du Sud, une relation non reconnue dans des reconstructions récentes [44], comp. Fig. 6. Gris foncé : futurs terranes Alpins ; domaines pointillés : bassins transtensionels du Carbonifère supérieur ; AM : massif Armoricain ; Aq : Aquitaine ; BM : massif Bohémien ; Ca : Alpes Carniques ; Ct : terranes Cantabrien ; Clb : Ibérie centrale ; Ext : massifs externes Alpins ; Ka-Ba : Kabylies-Baléares ; MC : Massif central ; Ms : meseta Marocainne ; OM : Ossa Morena ; Py : Pyrénées ; Sa : Sardaigne ; S-A : socle des Alpes Sud ; SP : future zone SudPortugaise ; Sx : Saxothuringien; WL : terrane ouest Asturien-Léonais.

time, the Palaeotethys oceanic ridge started to subduct underneath the accreted cordillera, in a strike-slip tectonic environment (Fig. 5). The Late Carboniferous collision between Gondwana and Laurentia produced the large Alleghanian orogen. The Variscan belt of
Europe represented the transition between this Himalaya type collision and the still active margin in the east (Tethyan area [64]). The collapse of the European cordillera occurred as early as $320 \mathrm{Ma}$ in response to the roll-back effect of the Paleotethys subducting slab 


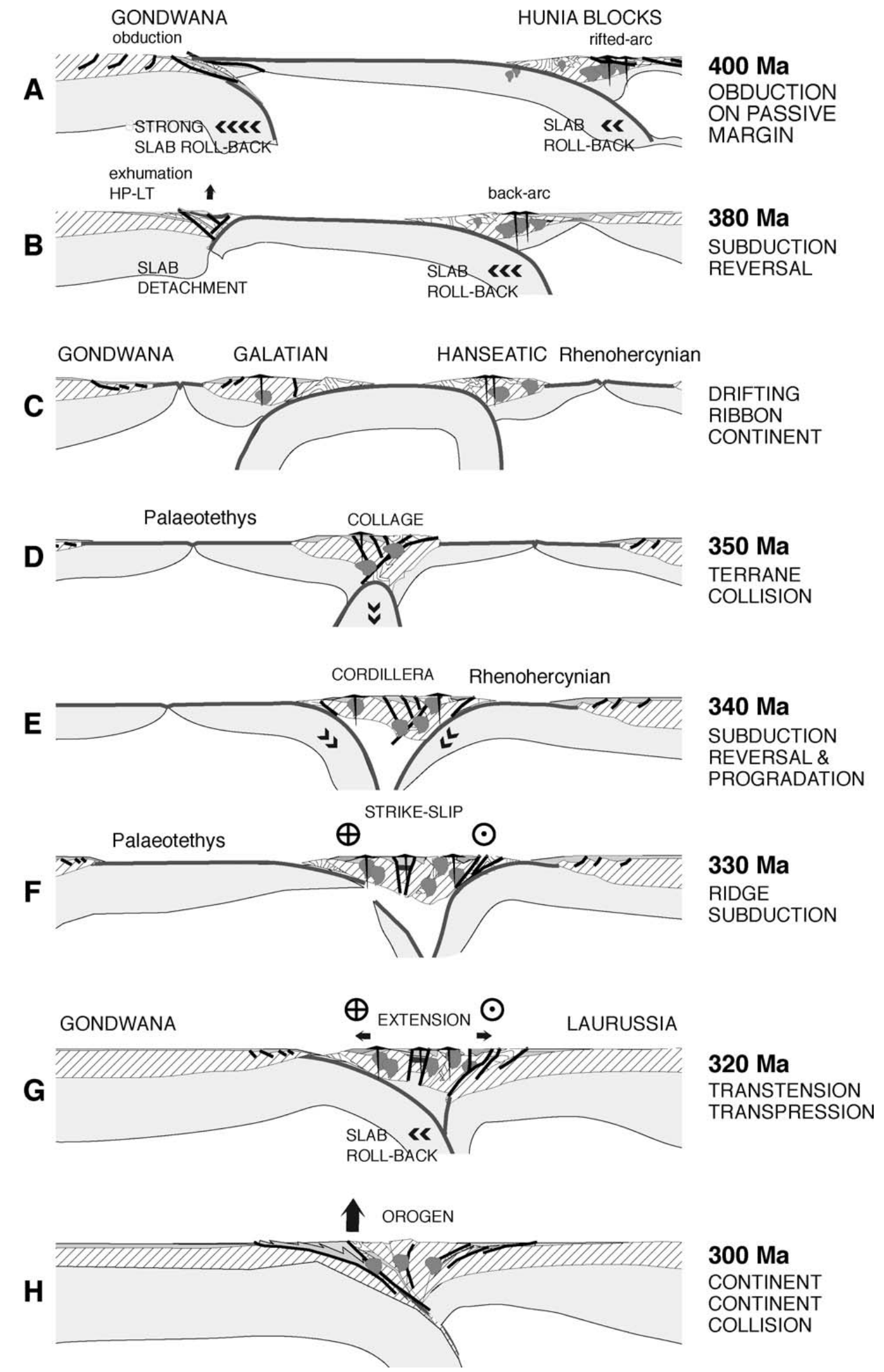

Fig. 6. Cross-sectional palinspastic model for the plate tectonic Variscan evolution of the Alpine basement and its framework (see explanations in text). Gondwana is regarded as fixed, whereas the right sides of the model move in and out of the sections. A. Obduction of oceanic crust on the Gondwana passive margin. B. Subduction reversal, exhumation of HP-HT units on the Gondwana side. C. Onset of the opening of Palaeotethys with separation of the Galatian Terranes; opening of the Rhenohercynian Ocean. D. Terrane collision. E. Subduction reversal and progradation. F. Ridge subduction. G. Extension, transtension-transpression. H. Continent-continent collision, uplift of orogen. 
(Fig. 6G) [66], accompanied by transtensional and transpressional tectonic events. The 330-320 Ma time span is detailed on Fig. 5 both in map and cross section, to show better the location of the various Gondwanaderived terranes, and this map may explain the geodynamic setting during the late Variscan in a different way than previous models [45]. The final juxtaposition of continental pieces was realised through large-scale displacement within the collapsing cordillera. In the general framework, the Variscan orogeny resulted from the oblique, anticlockwise collision of Gondwana with Laurussia during Early Carboniferous times [28], and specific terranes underwent considerable rotations and migration during the Late Carboniferous [22]. Different existing models of large-scale strike-slip have been applied to the Late Variscan juxtaposition of microcontinental pieces $[44,45]$.

Very similar palaeogeographic configurations with differing plate-tectonic interpretations were nearly contemporaneously submitted $[45,63,67]$, introducing the still active Palaeotethys domain and inducing also large-scale dextral transcurrent movements in the Alpine areas [34]. Strike-slip, contemporaneous sedimentation and crustal shortening with southverging nappe structures were located at the active margin of Laurussia [45]. When the Galicia-Southern Brittany Ocean closed [45], the Palaeotethys remained open [64], but both realms represent the diachronous evolution of one oceanic realm, the Palaeotethys Ocean. Slab roll-back induced the above-described Late Carboniferous/Permian extension and magmatic activity, evolving towards back-arc opening during the Triassic $[64,70]$. The subsequent tectonic evolution characteristic for the Alpine domain was dominated by the Alpine plate tectonic configurations [65] leading to the final juxtaposition of crustal pieces, which, formerly, were parts of the Galatian continental ribbon.

A dynamic plate-tectonic evolution with interaction of ribbon-continents [63,68] better explains the observed pre-Mesozoic assemblages, and it is to hope that the different working groups or schools may find a consensus for the evidently remaining problems, which may result from comparing information concerning different crustal levels.

\section{Acknowledgments}

René Pierre Ménot (Saint-Étienne) kindly added his constructive thoughts to an early version of this paper, and the interesting suggestions and corrections by Christopher Johnson (Houston), Franz Neubauer (Salzburg) and an anonymous reviewer are highly appreciated, although some wishes could unfortunately not be fulfilled. Karel Schulmann (Strasbourg) kindly helped to find a satisfying final version of this paper.

\section{References}

[1] J.-P. Bellot, C. Triboulet, C. Laverne, G. Bronner, Evidence for two burial/exhumation stages during the evolution of the Variscan belt, as exemplified by P-T-t-d paths of metabasites in distinct allochtonous units of the Maures massif (SE France), Int. J. Earth Sciences 92 (2003) 7-26.

[2] B. Bonin (coord.), P. Brändlein, F. Bussy, J. Desmons, U. Eggenberger, F. Finger, K. Graf, Ch. Marro, I. Mercolli, R. Oberhänsli, A. Ploquin, A. von Quadt, J. von Raumer, U. Schaltegger, H. P. Steyrer, D. Visona, G. Vivier, Late Variscan magmatic evolution, in: J. von Raumer and F. Neubauer (Eds.) The Pre-Mesozoic Geology in the Alps. Springer, Heidelberg, 1993, pp. 171-201.

[3] P. Brändlein, G. Nollau, Z. Sharp, J. von Raumer, Petrography and geochemistry of the Vallorcine-Granite (Aiguilles-Rouges Massif, western Alps), Schweiz, Min. Petr. Mitt 74 (1994) 227-243.

[4] J.P. Burg, J. van den Driessche, J.P. Brun, Syn- to postthickening extension in the Variscan belt of western Europe, modes and structural consequences, Geol. France (1994) 33-51.

[5] F. Bussy, Pétrogenèse des enclaves microgrenues associées aux granitoïdes calc-alcalins: exemple des massifs varisques du Mont-Blanc (Alpes occidentales) et miocène du Monte Capanne (île d'Elbe, Italie), Ph.D. Thesis, Mem. Géologie (Lausanne), 7, 1990, p. 309.

[6] F. Bussy, J. Hernandez, J. von Raumer, Bimodal magmatism as a consequence of the postcollisional readjustment of the thickened Variscan continental lithosphere (Aiguilles-Rouges/Mont-Blanc massifs, western Alps), Trans. R. Soc. Edinburgh Earth Sc. 91 (2000) 221-233.

[7] N. Capuzzo, F. Bussy, High-precision dating and origin of synsedimentary volcanism in the Late Carboniferous Salvan Doreénaz basin (Aiguilles-Rouges Massif, western Alps), Schweiz. Min. Petr. Mitt 80 (2000) 147-167.

[8] N. Capuzzo, F. Bussy, Synsedimentary volcanism in the Late Carboniferous Salvan-Dorénaz basin (western Alps), Ann. Mus. Civ. Sc. Nat. Brescia. Monogr. 25 (2001) 203-211.

[9] N. Capuzzo, R. Handler, F. Neubauer, A. Wetzel, Postcollisional rapid exhumation and erosion during continental sedimentation:

Fig. 6. Modèle en coupes palinspastiques de l'évolution de la tectonique des plaques Varisques pour le socle Alpin et son cadre géologique contemporain (voir explications dans le texte). Le Gondwana est considéré comme fixe, et les parties est du modèle entrent ou sortent des coupes spécifiques. A. Obduction de la croûte océanique sur la marge passive de Gondwana. B. Inversion de la subduction, exhumation des unités HP-HT du côté Gondwana. C. Commencement de l'ouverture de l'océan Rhéno-hercynien. D. Collision des terranes. E. Inversion de subduction et progradation. F. Subduction de la ride. G. Extension, transtension-transpression. H. Collision continent-continent, surélévation de l'orogène. 
the example of the late Variscan Salvan-Dorénaz basin (western Alps), Int. J. Earth Sciences 92 (2003) 364-379.

[10] N. Capuzzo, A. Wetzel, Facies and basin architecture of the Late Carboniferous Salvan-Dorénaz continental basin (western Alps, Switzerland/ France), Sedimentology 51 (2004) 675-697.

[11] M. Chiaradia, Metal source in the W-As-Au skarn of Salanfe (Aiguilles-Rouges Massif, Swiss Alps): Attempt of identification using $\mathrm{Pb}$ isotopes, in : H. Papunen (Ed.), Mineral Deposits: Research and Exploration Where Do They Meet?, A.A. Balkema, Rotterdam, 1997, pp. 621-624.

[12] A. Cocherie, P. Rossi, Respective roles of source composition and melting conditions in the high-K content of some magmas: geochemical constraints, in: M. Brown, P.M. Piccoli (Eds.), The Origin of Granites and Related Rocks, 3rd Hutton symposium on the origin of granites and related rocks, U. S. Geological Survey Circular, 1995, pp. 36-37.

[13] F. Colombo, F. Ghiglione, R. Compagnoni, Relitti di porfidi granitici a xenoliti granulitici nelle migmatiti dell'Argentera (Alpi Marittime), Plinius 10 (1993) 113-116.

[14] F. Colombo, B. Lombardo, R. Compagnoni, L. Delle Piani, Le granuliti leucocrate: nuova unita' premigmatica nel massicio cristallino dell'Argentera (Alpi Marittime), Plinius 14 (1995) 118-119.

[15] F. Debon, M. Lemmet, Evolution of $\mathrm{Mg} / \mathrm{Fe}$ ratios in late Variscan plutonic rocks from the External Crystalline Massifs of the Alps (France, Italy, Switzerland), J. Petrol. 40 (1999) 1151-1185.

[16] F. Debon, C. Guerrot, R.P. Ménot, G. Vivier, A. Cochérie, Late Variscan granites of the Belledonne massif (French Western Alps): an Early Visean magnesian plutonism, Schweiz. Min. Petr. Mitt. 78 (1998) 69-87.

[17] E. Desor, Der Gebirgsbau der Alpen, C.W. Kreidel, Wiesbaden, $1865,, 151 \mathrm{p}$

[18] E. Desor, Sur la disposition des massifs cristallins des Alpes ou zones d'affleurement, Bull. Soc. Geol. France 2 (1865) 360-364.

[19] C. Dobmeier, Die variskische Entwicklung des südwestlichen Aiguilles-Rouges Massives (Westalpen, Frankreich), Mémoires de Géologie (Lausanne) 29 (1996) 191.

[20] C. Dobmeier, Variscan P-T deformation paths from the southwestern Aiguilles-Rouges massif (External massif, western Alps) and their implication for its tectonic evolution, Geol. Rundsch. 87 (1998) 107-123.

[21] C. Dobmeier, H.R. Pfeifer, J.F. von Raumer, The newly defined "Greenstone Unit" of the Aiguilles-Rouges massif (western Alps): remnant of an early Palaeozoic oceanic island-arc? Schweiz. Min. Petr. Mitt. 79 (1999) 263-276.

[22] J.B. Edel, The rotations of the Variscides during the Carboniferous collision: paleomagnetic constraints from the Vosges and the Massif Central /France), Tectonophysics 332 (2001) 69-92.

[23] M. Faure, E. Bé Mézème, A. Cocherie, P. Rossi, A. Chemenda, D. Boutelier, Devonian geodynamic evolution of the Variscan Belt, insights from the French Massif Central and Massif Armoricain, Tectonics 27 (2008) TC2005, doi:10.1029/ 2007TC002115.

[24] A. Fernandez, S. Guillot, R.P. Ménot, P. Ledru, Late Paleozoic polyphased tectonics in the SW Belledonne massif (external crystalline massifs, French Alps), Geodinamica Acta 15 (2002) 127-139.

[25] J. Fernández-Suárez, R. Arenas, J. Abati, J.R. Martínez Catalán, M. J. Whitehouse, and T.E. Jeffries, U-Pb chronometry of polymetamorphic high-pressure granulites: An example from the allochthonous terranes of the NW Iberian Variscan belt, in: R.D. Jr Hatcher, M.P. Carlson, J.H. McBride, J.R. Martínez
Catalán (Eds.), 4-D Framework of Continental Crust: Geological Society of America Memoir 200, 2007, pp. 469-488.

[26] S. Ferrando, D. Rubatto, B. Lombardo, High-pressure-hightemperature Variscan metamorphism in the western Alps: petrological constraints from the Laghi del Frisson omphacite granulites (Argentera massif, Italy), FIST - Geoitalia 2007, Sesto Forum Italiano di Scienze della Terra, Rimini, Italy, 12-14 September 2007, Sessione 25: Evoluzione dei terranes gondwaniani e peri-gondwaniani nelle Variscidi delle Alpi, Appennini e del Massiccio Sardo-Corso, 2007.

[27] W. Franke, Tectonostratigraphic units in the Variscan belt of central Europe, Geol. Soc. Amer. Spec. 290 (1989) 67-89.

[28] W. Franke, Phanerozoic structures and events in Central Europe, in : D. Blundell, S. Mueller (Eds.), A Continent revealed, Cambridge University Press, 1992, pp. 164-180.

[29] W. Frisch, F. Neubauer, Pre-Alpine terranes and tectonic zoning in the eastern Alps, Geol. Soc. Amer. Spec. 230 (1989) 91-100.

[30] V. Gardien, J.M. Lardeaux, P. Ledru, P. Allemand, St. Guillot, Metamorphism during late orogenic extension: insights from the French Variscan belt, Bull. Soc. Geol. France 168 (1997) 271286.

[31] V. Gardien, M. Tegyey, M. Lardeaux, M. Misseri, E. Dufour, Crust-mantle relationships in the French Variscan chain: the example of the southern Monts du Lyonnais unit (eastern French Massif Central), J. Metam. Geol. 8 (1990) 477-492.

[32] D. Gebauer, The Pre-Alpine Evolution of the Continental Crust of the Central Alps: an overview, in : J. von Raumer, F. Neubauer (Eds.), The pre-Mesozoic Geology in the Alps, Springer, Heidelberg, New York, 1993, pp. 93-117.

[33] F. Genier, F. Bussy, J.L. Epard, L. Baumgartner, Water-assisted migmatization of metagraywackes in a Variscan shear zone, Aiguilles-Rouges massif, western Alps, Lithos 102 (2008) 575597.

[34] D. Giorgis, P. Thélin, G.M. Stampfli, F. Bussy, The Mont-Mort metapelites: Variscan metamorphism and geodynamic context (Briançonnais basement, western Alps, Switzerland), Schweiz. Min. Petr. Mitt. 79 (1999) 381-398.

[35] V. Grandjean, S. Guillot, A. Pêcher, Un nouveau témoin de l'évolution métamorphique BP-HT postorogénique hercynienne: l'unité de Peyre-Arguet (Haut Dauphiné), C. R. Acad. Sci. Paris. Ser. IIa 322 (1996) 189-195.

[36] S. Guillot, R.P. Ménot, Nappe stacking and first evidence of late Variscan extension in the Belledonne Massif (External Crystalline Massifs, French Alps), Geodinamica Acta 12 (1999) 97-111.

[37] S. Guillot, R.P. Ménot, J.M. Lardeaux, Tectonique intraocéanique distensive dans l'ophiolite paléozoïque de Chamrousse (Alpes occidentales), Bull. Soc. Geol. France 163 (1992) 229-240.

[38] M.J. Holdaway, Stability of andalusite and the aluminium silicate phase diagram, Am. J. Sci. 271 (1971) 97-131.

[39] V. Janousek, F. Holub, The causal link between HP-HT metamorphism and ultrapotassic magmatism in collisional orogens: case study from the Moldanubian Zone of the Bohemian Massif, Proceedings of the Geologists' Association 118 (2007) 75-86.

[40] P. Ledru, J.M. Lardeaux, D. Santallier, A. Autran, J.M. Quenardel, J.P. Floc'h, G. Lerouge, N. Maillet, J. Marchand, A. Ploquin, Où sont les nappes dans le Massif central français ? Bull. Soc. Geol. France 5-3 (1989) 605-618.

[41] P. Le Fort, Géologie du Haut-Dauphiné cristallin (Alpes françaises), Sci. Terre Mem. 25 (1973) 1-373.

[42] B. Lombardo, F. Colombo, R. Compagnoni, G. Ghiglione, D. Rubatto, Relics of pre-Variscan events in the Malinvern-Argentera Complex, Argentera Massif, western Alps, Abstract Volume 
of the 3rd workshop on Alpine Geological Studies, Oropa-Biella 1997, Quaderni de Geodinamica alpina e quaternaria. Milano, 4 (1997) 66.

[43] C. Marro, Organisation géochimique et intrusion du granite du Mont-Blanc et de deux leucogranites, Schweiz. Min. Petr. Mitt. 68 (1988) 521-529.

[44] J.R. Martínez Catalán, R. Arenas, F. Díaz García, P. González Cuadra, J. Gómez-Barreiro, J. Abati, P. Castiñeiras, J. Fernández-Suárez, S. Sánchez Martínez, P. Andonaegui, E. González Clavijo, A. Díez Montes, F.J. Rubio Pascual, B. Valle Aguado, Space and time in the tectonic evolution of the northwestern Iberian Massif: Implications for the Variscan belt, in: R.D. Jr. Hatcher, M.P. Carlson, J.H. McBride, J.R. Martínez Catalán (Eds.), 4-D Framework of Continental Crust: Geol. Soc. Amer. Mem. 200, 2007, pp. 403-423.

[45] P. Matte, The Variscan collage and orogeny (480-290 Ma) and the tectonic definition of the Armorica microplate: a review, Terra Nova 13 (2001) 122-128.

[46] R.P. Ménot, Les formations plutonovolcaniques dévoniennes de Rioupéroux-Livet (Massifs cristallins externes des Alpes françaises): nouvelles définitions lithostratigraphiques et pétrographiques, Schweiz. Min. Petr. Mitt. 66 (1986) 227-256.

[47] R. P. Ménot. Magmatismes paléozoiques et structuration carbonifère du Massif de Belledonne (Alpes françaises), Mem. et Doc. Centre Armoricain Études Structurales des Socles, Rennes 21 (1987), p. 465.

[48] R.P. Ménot, The geology of the Belledonne massif: an overview (External crystalline massifs of the western Alps), Schweiz. Min. Petr. Mitt. 68 (1988) 531-542.

[49] R.P. Ménot, M.G. Bonhomme, G. Vivier, Structuration tectonométamorphique carbonifère dans le massif de Belledonne (Alpes occidentales françaises): Apport de la géochronologie K/Ar des amphiboles, Schweiz. Min. Petr. Mitt. 67 (1987) 273-284.

[50] R.P. Ménot, J.L. Paquette, Geodynamic significance of basic and bimodal magmatism in the external domain, in : J. von Raumer, F. Neubauer (Eds.), The pre-Mesozoic Geology in the Alps, Springer, Heidelberg, 1993, pp. 241-254.

[51] R.P. Ménot, J.J. Peucat, D. Scarenzi, M. Piboule, 496 My age of plagiogranites in the Chamrousse ophiolite complex (External Crystalline Massifs in the French Alps): evidence of a Lower Paleozoic oceanization, Earth Planet. Sci. Lett. 88 (1988) 82-92.

[52] F. Oberli, M. Meier, G. Biino, Time constraints on the preVariscan magmatic/metamorphic evolution of the Gotthard and Tavetsch units derived from single-zircon $\mathrm{U}-\mathrm{Pb}$ results, Schweiz. Min. Petr. Mitt. 74 (1994) 483-488.

[53] L. Paquette, R.P. Ménot, J.J. Peucat, J.J. Ree, Sm-Nd and U-Pb zircon study of eclogites from the Alpine External massifs (western Alps): Evidence for crustal contamination, Earth Planet. Sci. Lett. 96 (1989) 181-198.

[54] A. Proyer, Metamorphism of pelites in NKFMASH: a new petrogenetic grid with implications for the preservation of high-pressure mineral assemblages during exhumation, Journal of Metamorphic Geology 21 (2003) 493-509.

[55] D. Rubatto, U. Schaltegger, B. Lombardo, F. Colombo, R. Compagnoni, Complex Paleozoic magmatic and metamorphic evolution in the Argentera massif (Western Alps) resolved with U-Pb dating, Schweiz. Min. Petr. Mitt. 81 (2001) 213-228.

[56] U. Schaltegger, D. Gebauer, Pre-Alpine geochronology of the central, western and southern Alps, Schweiz. Min. Petr. Mitt. 79 (1999) 79-87.

[57] U. Schaltegger, C.M. Fanning, D. Günther, J.C. Maurin, K. Schulmann, D. Gebauer, Growth, annealing and recrystallization of zircon and preservation of monazite in high-grade metamorphism: conventional and in situ U-Pb isotope, cathodoluminescence and microchemical evidence, Contrib. Mineral. Petrol 134 (1999) 186-201.

[58] U. Schaltegger, D. Gebauer, A. von Quadt, The mafic-ultramafic rock association of Loderio-Biasca (lower Pennine Nappes, Ticino, Switzerland): Cambrian oceanic magmatism and its bearing on Early Paleozoic paleogeography, Chemical Geology 186 (2002) 265-279.

[59] U. Schaltegger, J. Abrecht, F. Corfu, The Ordovician orogeny in the Alpine basement: constraints from geochronology and geochemistry in the Aar Massif (Central Alps), Schweiz. Min. Petr. Mitt. 83 (2003) 183-195.

[60] K. Schulmann, U. Schaltegger, J. Jezek, A.B. Thompson, J.B. Edel, Rapid burial and exhumation during orogeny: thickening and synconvergent exhumation of thermally weakened and thinned crust (Variscan orogen in western Europe), Am. J. Sci. 302 (2002) 856-897.

[61] B. Schultz, J. von Raumer, Syndeformational uplift of Variscan high-pressure rocks (Col de Bérard, Aiguilles-Rouges Massif, western Alps), Ztschr. Dt. Geol. Ges 144 (1993) 104-120.

[62] B. Schultz, K. Bombach, S. Pawlig, H. Bratz, Neoproterozoic to Early Palaeozoic magmatic evolution in the Gondwana-derived Austroalpine basement to the South of the Tauern Window (Eastern Alps), Int. J Earth Sci. 93 (2004) 824-843.

[63] G.M. Stampfli, G.D. Borel, A plate tectonic model for the Paleozoic and Mesozoic constrained by dynamic plate boundaries and restored synthetic oceanic isochrons, Earth Planet. Sci. Lett. 196 (2002) 17-33.

[64] G.M. Stampfli, H. Kozur, Europe from the Variscan to the Alpine cycles, in : D.G. Gee, R. Stephenson (Eds.), European lithosphere dynamics, 32, Geological Society, London, Memoirs, 2006, pp. 57-82.

[65] G.M. Stampfli, C. Hochard, Plate tectonics of the Alpine realm, in: J.B. Murphy, A.J. Hynes, J.D. Keppie (Eds.), Ancient Orogens and Modern Analogues, Geol. Soc. London, in press.

[66] G.M. Stampfli, J. Mosar, P. Favre, A. Pillevuit, J.-C. Vannay, Permo-Mesozoic evolution of the western Tethys realm: the Neo-Tethys East Mediterranean basin connection, in: P.A. Ziegler, W. Cavazza, A.H.F. Robertson, S. Crasquin-Soleau (Eds.), Peri-Tethys memoir 6, Peri-Tethyan rift/Wrench basins and passive margins. Mem Mus. Natn. Hist. Nat. 186, 2001, pp. 51-108.

[67] G.M. Stampfli, J. von Raumer, G. Borel, The Paleozoic evolution of pre-Variscan terranes: From Gondwana to the Variscan collision, Geol. Soc. Amer. 364 (2002) 263-280 (special paper).

[68] G.M. Stampfli, C. Hochard, J.F. von Raumer, Reconstructing the Palaeozoic Gondwana margin and its redistribution: new aspects, Geophys. Res. Abs. 8, EGU06-A-02708, 2006.

[69] A.B. Thompson, Heat, fluids, and melting in the granulite facies, in : D. Vielzeuf, P. Vidal (Eds.), Granulites and crustal evolution, Kluver Academic Publishers, Amsterdam, 1990, pp. 37-57.

[70] I. Vavassis, A. De Bono, G.M. Stampfli, D. Giorgis, A. Valloton, $\mathrm{Y}$. Amelin $\mathrm{Y}, \mathrm{U}-\mathrm{Pb}$ and $\mathrm{Ar}-\mathrm{Ar}$ geochronological data from the Pelagonian basement in Evia (Greece): Geodynamic implications for the evolution of paleo-Tethys, Schweiz. Min. Petr. Mitt 80 (2000) 21-43.

[71] J.F. von Raumer, The External massifs, relics of Variscan basement in the Alps, Geol. Rundsch. 73 (1984) 1-31.

[72] J.F. von Raumer, Les massifs du Mont-Blanc et des AiguillesRouges : témoins de la formation de croûte varisque dans les Alpes occidentales, Géologie Alpine 63 (1987) 7-24. 
[73] J.F. von Raumer, Caledonian-Variscan structures in the Alps: an introduction, Schweiz. Min. Petr. Mitt. 68 (1988) 291-299.

[74] J.F. von Raumer, The Palaeozoic evolution in the Alps: from Gondwana to Pangea, Geol. Rundsch. 87 (1998) 407-435.

[75] J.F. von Raumer, F. Neubauer (Eds.), The pre-Mesozoic geology in the Alps, Springer, Heidelberg, 1993, p. 677.

[76] J.F. von Raumer, F. Bussy, Mont-Blanc and Aiguilles-Rouges: Geology of their polymetamorphic basement (External massifs, France-Switzerland), Mémoires de Géologie (Lausanne) 42 (2004) 1-203.

[77] J. F. von Raumer. G. M. Stampfli, The birth of the Rheic Ocean: Early Palaeozoic subsidence patterns and subsequent tectonic plate scenarios. Tectonophysics 461 (2008) 9-20.

[78] J.F. von Raumer, R.P. Ménot, J. Abrecht, G. Biino, The PreAlpine evolution of the External massifs, in : J.F. von Raumer, F. Neubauer (Eds.), The pre-Mesozoic Geology of the Alps, Springer, Heidelberg, 1993, pp. 221-240.

[79] J.F. von Raumer, F. Bussy, Z.D. Sharp, Lac Cornu revisited: the evolution from lower to upper crust (Aiguilles-Rouges
Massif, western Alps), Schweiz. Min. Petr. Mitt. 76 (1996) 120-121.

[80] J.F. von Raumer, J. Abrecht, F. Bussy, B. Lombardo, R.P. Ménot, U. Schaltegger, The Palaeozoic metamorphic evolution of the Alpine External massifs, Schweiz. Min. Petr. Mitt. 79 (1999) 5-22.

[81] J.F. von Raumer, G.M. Stampfli, G. Borel, F. Bussy, The organization of pre-Variscan basement areas at the North-Gondwanan margin, Int. J. Earth Sciences 91 (2002) 35-52.

[82] J. F. von Raumer, Ch. Dobmeier, F. Bussy, Variscan structures in the Aiguilles-Rouges-Mont-Blanc areas (External massifs, Alps) Zentralblatt für Geologie und Paläontologie I, (2003) 3/4:1-6.

[83] J.F. von Raumer, G.M. Stampfli, F. Bussy, F. Gondwana-derived microcontinents: the constituents of the Variscan and Alpine collisional orogens, Tectonophysics 365 (2003) 7-22.

[84] J.F. von Raumer, G.M. Stampfli, C. Hochard, J.C. GutiérrezMarco, The Early Palaeozic in Iberia: a plate-tectonic interpretation, Z. Dt. Ges. Geowiss. 157 (2006) 575-584.

[85] P.J. Wyllie, Crustal anatexis: an experimental review, Tectonophysics 43 (1977) 41-71 